\title{
Effect of Blanching and Drying Temperatures on Various Physico-chemical Characteristics of Green Beans
}

\author{
Neelofar Manzoor, Aamir H. Dar, Shafat Khan, Hilal R. Hakeem, Hilal A. Makroo
}

10.18805/ajdfr.DR-1430

\begin{abstract}
Fresh green bean samples (un-blanched and blanched) were dried at 50,60 and $70{ }^{\circ} \mathrm{C}$, followed by studying the effect of blanching treatment and drying temperature in various characteristics and storage study in HDPE and LDPE packaging material. The blanched dried green bean samples showed lower ash content but higher rehydration ratio, chlorophyll content and carbohydrate content than un-blanched dried green bean samples. No significant change in moisture, protein, fat and fibre content was observed after blanching. The green beans were dried up to the moisture content of $14 \pm 0.5$ from an initial moisture content of $>90 \%$. The increase in the drying temperature reduced the drying time. Blanching treatment enhanced the drying rate, the kinetics parameter showed that the value of ' $\mathrm{k}$ ' ranged from $0.008-0.013$ and $0.009-0.015 / \mathrm{min}$ in un-blanched and blanched samples respectively. The drying temperature caused decrease in color parameters, chlorophyll content, however RR was observed to increase with the drying temperature. The moisture, chlorophyll content, color values $\left(L^{*} a^{*} b^{*}\right)$ and rehydration ratio was observed to decrease with the storage. The better desirable quality attributes of green beans were retained in HDPE as compared to LDPE. In conclusion it was suggested that drying temperature effects the quality attributes of the green beans and also the packaging material also influence the storage stability of the dried green beans.
\end{abstract}

Keywords: Blanching, Chlorophyll, Color, Drying, Green beans, Rehydration.

Asian Journal Of Dairy and Food Research (2019)

\section{INTRODUCTION}

G reen bean (Phaseolus vulgaris), is an annual herbaceous plant belonging to Fabaceae family that originated in Central and South America. Green beans are produced worldwide; in 2016 the total production of green beans was around 26.8 million tonnes. China is the largest producer followed by Indonesia, India, Turkey, Thailand, and Egypt, Indian alone produced around 620,000 tons green beans (FAOSTAT, 2018). When common bean is used for its unripe fruit, it is called as green bean or snap bean (Sotelo et al. (2003). The green beans are good source of vitamins, proteins and a significant source of minerals for low- income population (Laparra et al. 2009). Vitamin A and C present in green beans are excellent antioxidants that reduces the amount of free radicals in the body and prevent the building up of plaque in arteries and veins Soares, et al. 2015.

Green beans are highly perishable due to high moisture content (more than $90 \%$ ), thus they are vulnerable to microbial spoilage. Additionally the growth of beans is rapid at the time of harvest and exhibit comparatively higher respiration rate, even when held at low temperatures (Watada \& Morris, 1967, Maldonado et al. 1996). Green beans are occasionally cold stored for processing or favourable markets and can be stored up to 8-12 days under refrigerated conditions. Longer storage or higher temperatures hasten yellowing, seed development, and toughening of the pods as they contain high moisture content (WFLO-Worlds Food Logistis Organisation., 2008). However to extend their shelf life to many moths the drying process is most common method of green beans preservation.

Drying is a heat and mass transfer operation during which moisture is removed for the food material. The prime $\overline{\text { Department of Food Technology, Islamic University of Science \& }}$ Technology, Awantipora Kashmir 192122 India

Corresponding Author: Hilal Ahmad Makroo, Department of Food Technology, Islamic University of Science \& Technology, Awantipora Kashmir 192122 India, Email: hilalmakroo@gmail.com

How to cite this article: Manzoor, N., Dar, A.H., Khan, S., Hakeem, H.R. and Makroo H.A. (2019). Effect of Blanching and Drying Temperatures on Various Physico-chemical Characteristics of Green Beans. Asian Journal Of Dairy and Food Research, 38(3): 213-223.

Source of support: Nil.

Conflict of interest: None

Submitted:19-02-2019 Accepted:02-10-2019 Published: 31-10-2019

objective of drying is preservation by reducing the water activity hence enhancing the shelf life by reducing the possibility of microbial growth thus spoilage of food stuffs. Another objective is to reduce the bulk so that the product would be convenient and economical to handle, transport and store (Domyaz 2005 and 2011). Dried vegetables have great potential to use throughout the year for preparation of several types of mix vegetables and other recipes such as ingredient of ready to cook instant noodles, soup mixes etc. Traditional and conventional sun drying has many disadvantages which can be minimized by the mechanical hot air drying (Doymaz\& Pala, 2002). Hot air drying has gained importance because it has many advantages over sun drying, such as shorter drying times, lower labour costs, less microbial contamination, weather independent, controllable drying parameters which give more uniform and hygienic product with less quality degradation, (Barbosa-Canovas \& Vega Mercado, 1996). 
Drying characteristics of green beans have been studied by many authors There have been many studies on the drying behaviour of green beans such as Yaldiz and Ertekin, 2010 (green beans and skaush); Senadeera et al., 2003 (green beans); Doymaz et al., 2005 (green beans); Doymaz. 2011 (green beans and okra); Doymaz et al., 2015a (green beans); Doymaz et al., 2015b (green beans). However, any study regarding the effect of blanching on the drying and quality characteristics of green beans and their storage behaviour has not been found reported in literature to the best knowledge of the authors of the present study. Therefore, the present investigation was undertaken to study the effect of blanching treatment on drying characteristics and various parameters of dried green beans and their storage study.

\section{Materials and methods}

Fresh green beans were procured from local market of Awantipora, Kashmir India and kept in refrigerator (Model: GL-B285BGPN) at $5 \pm 2^{\circ} \mathrm{C}$ prior to use not more than 10 hours. Before drying process, green beans were washed, both ends were rejected and endless green beans were cut manually into pieces of length of $1.5 \pm 0.1 \mathrm{~cm}$. The green beans were further subdivided into 2 equal portions, one portion of green beans was pre-treated prior to drying by using the method of blanching given in Agarwal et al. 2015 and other portion was dried without any treatment (un-blanched).

\section{Standardization of blanching treatment}

A known quantity $(100 \mathrm{~g})$ of green beans was taken in a muslin cloth and dipped in boiling water containing 0.5 $\%$ sodium meta-bi-sulphite, $0.1 \%$ magnesium oxide, $0.1 \%$ sodium bicarbonate (1:5, W/W) for 1, 2, 3, 4 and 5 minutes for blanching treatment. Blanching time was standardized by checking the peroxidase activity with the help of peroxidase test solution ( $1 \%$ guaiacol and $2 \%$ hydrogen peroxide, 1:1).

\section{Peroxidase activity test}

The enzyme activity test was carried out by following the method described by Nleya et al. 2014.Ten randomly selected green bean pieces were cut into halves longitudinally and the 20 halves were arranged with cotyledon surface exposed and sprayed with peroxidase test solution. When the brown color developed in more than one out of 20 halves within 10 seconds of time after spraying the test solution, the treatment was considered as inadequate, the test was carried out in triplicates.

\section{Drying of the green beans}

The drying process was carried out in laboratory scale hot air dryer (Vindhawashani Engineering, New Delhi India). Both un-blanched and blanched samples were distributed uniformly in a single layer on the stainless steel tray, and dried at 50,60 and $70^{\circ} \mathrm{C}$ air temperatures. The change in weight during drying of each samples was measured at an interval of $30 \mathrm{~min}$. The samples were dried up to the final moisture level of $14 \pm 0.5 \%$.
To find out the rate constant ${ }^{\prime} \mathrm{k}^{\prime}\left(\mathrm{min}^{-1}\right)$ the change in moisture content with drying time was fitted to an exponential model, Eq. 1.

$$
M C=M C_{0} e^{-b t}
$$

Where $\mathrm{MC}_{0}$ and $\mathrm{MC}$ is the moisture content (d.b.)

\section{Packaging and storage}

Dried green bean samples were packed in different packaging materials: LDPE (Low Density Polyethylene) and HDPE (High Density Polyethylene) pouches. Packed samples were stored at ambient temperature up to 2 months for storage. The physicochemical analysis of the stored products was carried out at an interval of 30 days during storage.

\section{Proximate analysis}

The fresh as well as dried green bean samples were analysed for moisture, ash, crude protein, crude fibre, crude fat and carbohydrate content, all the parameters were determined by standard methods of AOAC 1990..The moisture content was estimated by oven drying method at $100-105^{\circ} \mathrm{C}$ to constant weight. Ash content was determined by incineration in muffle furnace (NSW-101/ Narang Scientific Works PVT. LTD. New Delhi, India) maintained at $550-600^{\circ} \mathrm{C}$ for $5-6 \mathrm{~h}$, protein by micro-Kjeldahl method, fat by Soxhlet extraction method and crude fibre was estimated by using dilute acid $\left(\mathrm{H}_{2} \mathrm{SO}_{4}\right)$ and alkali $(\mathrm{NaOH})$ hydrolysis. The total carbohydrate content was calculated by difference method using Eq. 2 .

$$
\text { Carbohydrate }=100-\left(\begin{array}{l}
\text { moisture }+ \text { ash }+ \text { fat }+ \\
\text { protein }+ \text { crudefibre }
\end{array}\right)
$$

\section{Color analysis}

The color of fresh as well as dried green bean samples was determined by using Colorimeter (Hunter Lab Color flex EZ Model No. 45/0). This instrument was calibrated by using supplied black and white tile provided with the instrument. The color parameters $\mathrm{L}^{*}$ (lightness), $\mathrm{a}^{*}$ (green to redness) and $b^{*}$ (blue to yellowness) were determined for every sample. Three readings were performed for each sample, and the corresponding mean and standard deviation were calculated.

\section{Chlorophyll analysis}

Chlorophyll content was determined by spectrophotometer method as recommended by Sadasivam and Manickam (1992). One gram of sample was crushed with $20 \mathrm{~mL}$ of 80 $\%$ acetone repeatedly in mortar and pestle. The extract was removed and the residue was crushed repeatedly until the residue was colorless. The extracts were filtered into $100 \mathrm{~mL}$ volumetric flask and made volume up to $100 \mathrm{~mL}$ with $80 \%$ acetone. The absorbance of the final volume was measured using UV-Vis spectrophotometer at the wavelength of $645,663 \mathrm{~nm}$ against blank solvent ( $80 \%$ acetone), and the chlorophyll content was calculated by Eq. 3 .

$$
\begin{aligned}
& \text { Total chlorophyll }(\mathrm{mg} / \mathrm{g})=20.2\left(A b s_{i 45}\right)+ \\
& 8.02\left(A b s_{663}\right) \frac{V}{1000 \times W}
\end{aligned}
$$


Where, $\mathrm{V}=$ Final volume of chlorophyll extract in $80 \%$ acetone and $\mathrm{W}=$ Fresh weight of the tissue extracted.

\section{Rehydration ratio}

Rehydration is a process of refreshing the dried material in water. The rehydration ratio was calculated by the method as recommended by Doymaz et al. (2015a). About 3 grams (W) of dried sample were placed in glass beakers containing water (at room temperature $25 \pm 2^{\circ} \mathrm{C}$ ) at a ratio of 1:100 (w/w) for 5 hours. The samples were stained and the excess water from the sample surface was removed by using tissue paper followed by the weighing $\left(\mathrm{W}_{1}\right)$. The rehydration ratio $(R R)$ was calculated using Eq. 4.

Rehydration ratio $(g$ water/dry matter $)=\frac{W 1-W}{W}$ Eq. (4)

Where, $\mathrm{W}=$ Weight of dried material and $\mathrm{W}_{1}=$ Weight of rehydrated material.

\section{Statistical analysis}

The experiments were run in triplicates and the mean values with standard deviations were reported. SPSS software (SPSS 16, Inc, Chicago, IL,USA) was used for Two-way Analysis of Variance (ANOVA) and Tukey's range Post-hoc test was used to identify the significant difference at $95 \%$ confidence level $(\alpha=0.05)$. The present study only discuses the main effects as the interactions were found not significant.

\section{Result AND DISCUSSION}

The fresh green beans were analyzed for moisture, ash, fat, protein, fibre, carbohydrate, color and chlorophyll. The results are presented in Table 1 and are almost similar to those reported by Doymaz et al., 2015a; Doymaz et al., 2015b; Belitz et al.,2009.

\section{Peroxidase activity}

Peroxidase is used as an indicator enzyme to evaluate adequacy of blanching because of its highest thermal

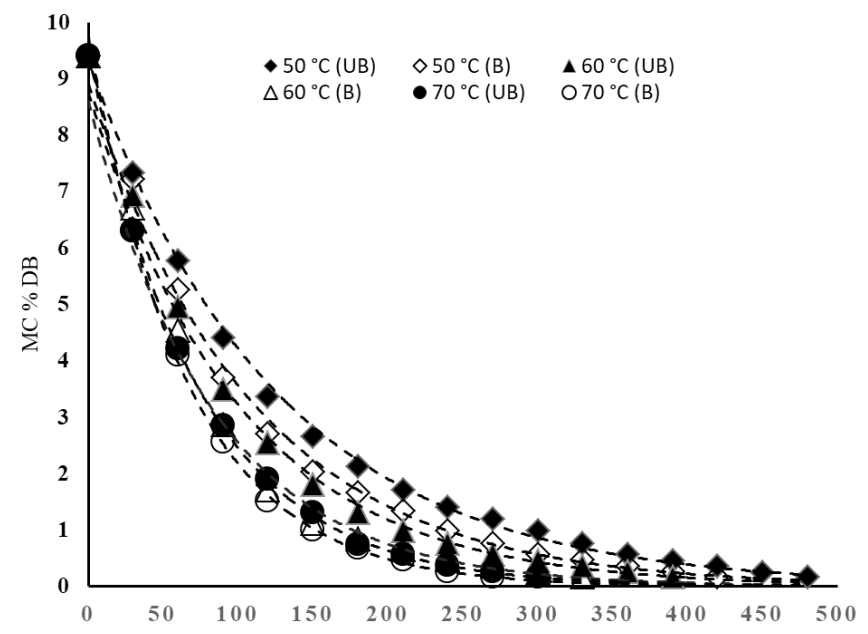

Figure 1: Drying curve of blanched (B) and un-blanched (UB) green beans dried at different temperatures (legends show actual data and dotted line (- - - ) shows model line resistance among all the enzymes (Gunes \& Bayindirh., 1993). Peroxidase activity was measured by color development within 10 seconds after spraying the test solution of guiacol and $\mathrm{H}_{2} \mathrm{O}_{2}$ (Nleya et al., 2014). From the results, it was observed that green bean samples in blanching solution for 3 or more than 3 min showed no peroxidase activity or negative peroxidase test. No brown color development was witnessed as the test solution was sprayed in samples blanched for more 3 or than $3 \mathrm{~min}$. Therefore the $3 \mathrm{~min}$ of blanching time was selected as standard blanching time for green beans and was used for further experiment in the present study. Further the un-blanched and blanched ( $3 \mathrm{~min}$ ) green bean samples were dried at three different temperatures viz 50,60 and $70{ }^{\circ} \mathrm{C}$ up to the moisture content of $14 \pm 0.5 \%$.

\section{Drying of blanched and un-blanched green beans}

The initial average moisture content of green beans was observed to be more than $90 \%$. The samples were dried at three different temperatures $\left(50,60\right.$ and $\left.70^{\circ} \mathrm{C}\right)$ until the final moisture content reached to $14 \pm 0.5 \%$, the drying curve at 50,60 and $70{ }^{\circ} \mathrm{C}$ are presented in Figure 1. It is apparent that the moisture content decreased with drying time and decreased faster at higher drying temperature in all the samples. Blanched samples showed shorter drying time than un-blanched samples, thus the drying time required to reach final moisture content of samples was 480, 360 and 300 min in case of un-blanched samples and 420, 300 and $240 \mathrm{~min}$ in case of blanched samples at drying temperature of 50,60 and $70^{\circ} \mathrm{C}$, respectively. This phenomenon can be explained by the fact that in addition to the enzyme inactivation blanching resulted in tissue softening, subsequently resulting in faster moisture removal by enhancing moisture transfer from inside the samples to the surface (Kshetrimayum et al., 2015).. The most effectual force governing the moisture movement in the agricultural products is diffusion and rate of diffusion can be enhanced with rise in temperature of heat input (Pardeshi et al., 2009). Thus, at higher drying temperature the higher heat absorption resulted in higher product temperature and relatively faster rate and consequently shorter drying time (Doymaz et al., 2015b). Similar observations were also reported by Shete et al. (2015) in green peas; Tunde-

Table 1: Physicochemical composition of fresh green beans

\begin{tabular}{ll}
\hline Component & Amount \\
\hline Moisture $(\mathrm{g} / 100 \mathrm{~g})$ & $90.39 \pm 0.40$ \\
Ash $(\mathrm{g} / 100 \mathrm{~g})$ & $0.50 \pm 0.00$ \\
Protein $(\mathrm{g} / 100 \mathrm{~g})$ & $1.82 \pm 0.60$ \\
Fat $(\mathrm{g} / 100 \mathrm{~g})$ & $0.23 \pm 0.05$ \\
Crude fibre $(\mathrm{g} / 100 \mathrm{~g})$ & $3.37 \pm 0.20$ \\
Carbohydrate $(\mathrm{g} / 100 \mathrm{~g})$ & $3.69 \pm 0.10$ \\
Chlorophyll content $(\mathrm{mg} / 100 \mathrm{~g})$ & $14.92 \pm 0.12$ \\
Color value & \\
$\mathrm{L}^{*}$ & $50.9 \pm 0.75$ \\
$\mathrm{a}^{*}$ & $-11.01 \pm 0.35$ \\
$\mathrm{~b}^{*}$ & $20.62 \pm 0.51$ \\
\hline
\end{tabular}


Akintunde (2014) in bell pepper; Rajeshwari et al. (2013) in amaranth leaves; Doymaz et al. (2015a) in green beans.

The kinetic parameters are presented in Table 2, the determination coefficient or $\mathrm{R}^{2}$ value of all the drying curves ranged from 0.993-0.999. Thus the change in moisture content with drying time was well described by exponantional reduction as depicted in Figure 1 . The rate constant ' $k$ ' increased with increasing the drying temperature; however the effect of blanching on drying rate was fairly witnessed by the value of the ' $k$ '. The value of ' $k$ ' ranged from $0.008-0.013$ and $0.009-0.015 / \mathrm{min}$ in un-blanched and blanched samples respectively, indicating the higher rate of drying in blanched samples than that of un-blanched. The un-blanched and blanched green bean samples dried at different temperatures up to the moisture content of $14^{\circ} 0.5 \%$ are presented as Figure 2 and 3 respectively.

\section{Effect of blanching and drying temperatures on physicochemical parameters}

\section{Proximate composition}

Moisture, crude fat and crude protein was not significantly affected by blanching and drying temperatures as shown in Table 3 and was found to be in the range of (13.88-14.09), (1.98-2.07) and (18.12-18.29), respectively. Gouveia et al. (2014); Doymaz et al., 2015 ${ }^{\mathrm{a}}$; Doymaz et al., 2015 ${ }^{\mathrm{b}}$ also reported the similar results in dried green beans. The ash content of both un-blanched and blanched dried green beans decreased significantly ( $p \leq 0.05$ ) from $4.87-4.33 \%$ and $4.41-$ $3.96 \%$, respectively with the increase in drying temperature. This lower ash content at high temperature may be due to high drying temperature resulting in the degradation of micronutrients. Similar trend was also reported by Reis et al.

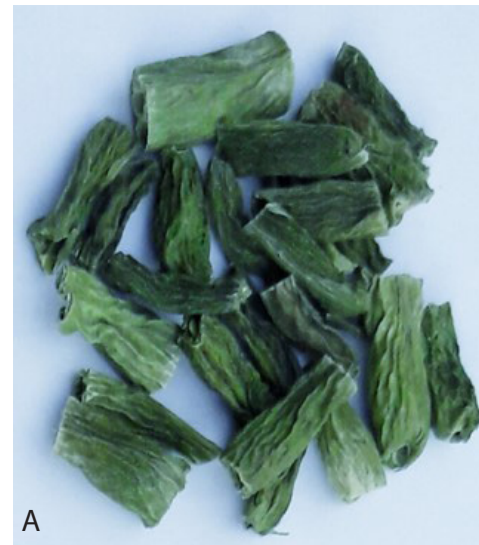

Figure 2: Un-blanched and dried at (a) 50, (b) 60 and (c) $70^{\circ} \mathrm{C}$
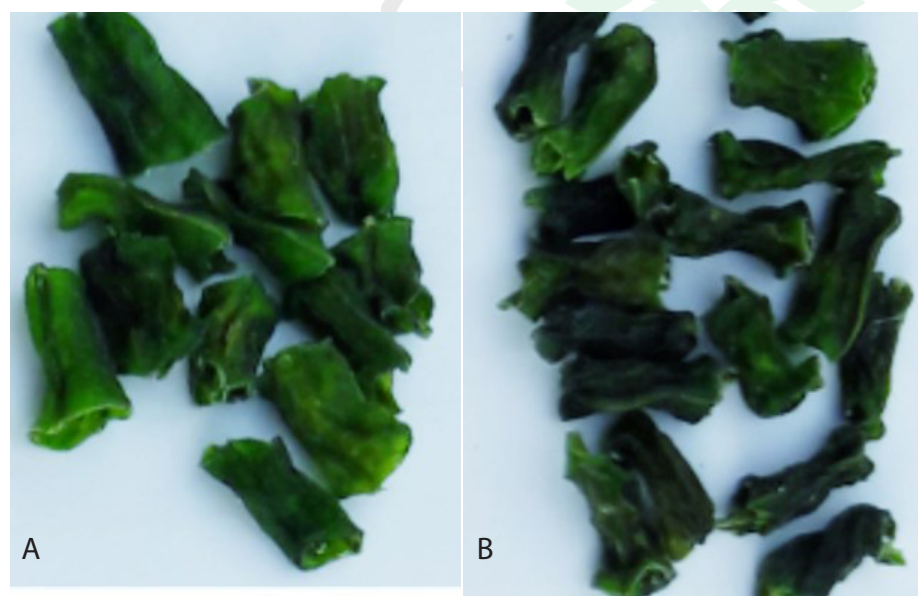

\section{C}
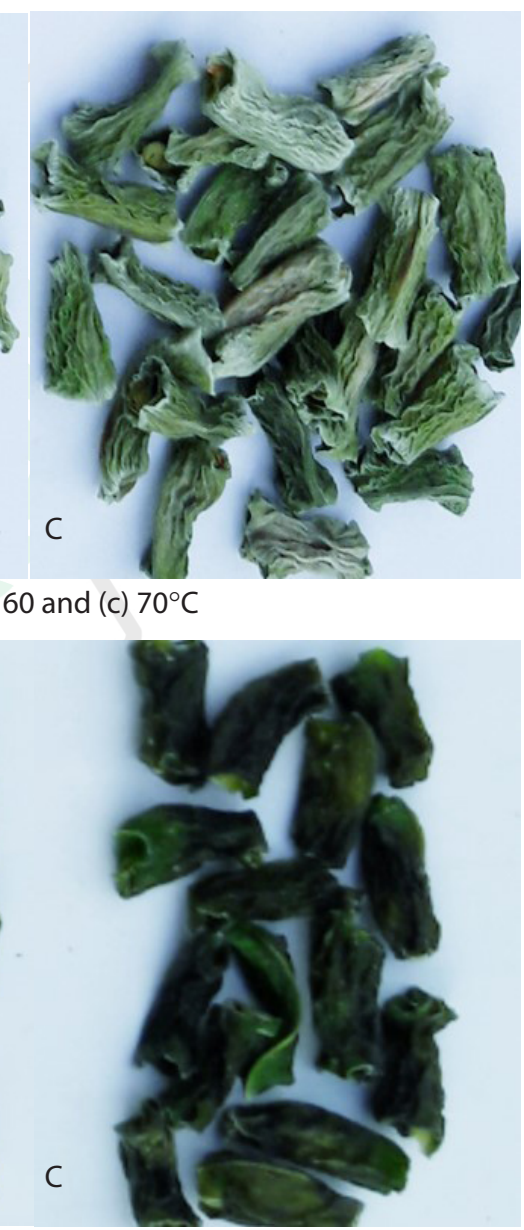

Figure 3: Blanched and dried at (a) 50, (b) 60 and (c) $70^{\circ} \mathrm{C}$

Table 2: Exponential Model parameters of drying of blanched and un0blanched green beans

\begin{tabular}{lllll}
\hline Treatment & Drying Temperature & $M C_{0}(g / g d r y$ weight $)$ & $-k\left(\mathrm{~min}^{-1}\right)$ & $R^{2}$ \\
\hline Un-blanched & 50 & 9.296 & 0.008 & 0.995 \\
& 60 & 8.761 & 0.010 & 0.997 \\
Blanched & 70 & 9.461 & 0.013 & 0.999 \\
& 50 & 8.903 & 0.009 & 0.996 \\
& 60 & 8.604 & 0.012 & 0.993 \\
& 70 & 9.738 & 0.015 & 0.999 \\
\hline
\end{tabular}


Effect of Blanching and Drying Temperatures on Various Physico-chemical Characteristics of Green Beans

Table 3: Effect of pre-treatment and different drying temperatures on physicochemical parameters of dried green beans

\begin{tabular}{|c|c|c|c|c|c|c|}
\hline \multirow[b]{3}{*}{ Parameter } & \multicolumn{3}{|c|}{ Un-blanched and dried } & \multicolumn{3}{|c|}{ Blanched and dried } \\
\hline & \multicolumn{6}{|c|}{ Drying Temperature $\left({ }^{\circ} \mathrm{C}\right)$} \\
\hline & 50 & 60 & 70 & 50 & 60 & 70 \\
\hline Moisture \% & $14.09 \pm 0.00^{\mathrm{a}}$ & $14.00 \pm 0.11^{\mathrm{a}}$ & $13.90 \pm 0.15^{\mathrm{a}}$ & $14.00 \pm 0.11^{\mathrm{a}}$ & $13.96 \pm 0.08^{\mathrm{a}}$ & $13.88 \pm 0.05^{\mathrm{a}}$ \\
\hline Fat $\%$ & $2.07 \pm 0.06^{\mathrm{a}}$ & $2.01 \pm 0.05^{\mathrm{a}}$ & $1.99 \pm 0.02^{\mathrm{a}}$ & $2.06 \pm 0.04^{\mathrm{a}}$ & $1.98 \pm 0.03^{\mathrm{a}}$ & $1.98 \pm 0.03^{\mathrm{a}}$ \\
\hline Ash \% & $4.87 \pm 0.13^{\mathrm{a}}$ & $4.58 \pm 0.11^{b}$ & $4.33 \pm 0.06^{c}$ & $4.41 \pm 0.02^{c}$ & $4.13 \pm 0.04^{d}$ & $3.96 \pm 0.06^{\mathrm{e}}$ \\
\hline Protein \% & $18.29 \pm 0.05^{\mathrm{a}}$ & $18.25 \pm 0.06^{\mathrm{a}}$ & $18.23 \pm 0.05^{\mathrm{a}}$ & $18.18 \pm 0.08^{\mathrm{a}}$ & $18.15 \pm 0.08^{\mathrm{a}}$ & $18.12 \pm 0.09^{\mathrm{a}}$ \\
\hline Fibre \% & $15.06 \pm 0.11^{\mathrm{a}}$ & $14.90 \pm 0.08^{b}$ & $14.69 \pm 0.09^{c}$ & $14.97 \pm 0.10^{a}$ & $14.77 \pm 0.01^{b c}$ & $14.59 \pm 0.11^{c}$ \\
\hline Carbohydrate \% & $45.62 \pm 0.10^{f}$ & $46.26 \pm 0.15^{\mathrm{de}}$ & $46.86 \pm 0.1^{1 c}$ & $46.38 \pm 0.12^{d}$ & $47.01 \pm 0.12^{b}$ & $47.47 \pm 0.11^{\mathrm{a}}$ \\
\hline RR (g water/g dry matter) & $2.26 \pm 0.17^{f}$ & $2.73 \pm 0.11^{\mathrm{e}}$ & $2.95 \pm 0.14^{d}$ & $3.41 \pm 0.18^{c}$ & $3.75 \pm 0.13^{b}$ & $4.14 \pm 0.12^{\mathrm{a}}$ \\
\hline Chlorophyll (mg/100g) & $82.51 \pm 0.09^{b}$ & $73.22 \pm 0.14^{\mathrm{e}}$ & $64.29 \pm 0.17^{f}$ & $88.54 \pm 0.19^{a}$ & $79.93 \pm 0.17^{c}$ & $73.78 \pm 0.15^{d}$ \\
\hline \multicolumn{7}{|l|}{ Color value } \\
\hline$L^{*}$ & $41.76 \pm 0.98^{\mathrm{a}}$ & $40.08 \pm 0.22^{b}$ & $39.60 \pm 0.53^{c}$ & $24.90 \pm 0.26^{d}$ & $21.94 \pm 0.52^{\mathrm{e}}$ & $21.02 \pm 0.18^{e}$ \\
\hline$a^{*}$ & $-4.78 \pm 0.43^{b}$ & $-4.10 \pm 0.13 a^{b}$ & $-3.98 \pm 0.16 a^{b}$ & $-4.57 \pm 0.96^{b}$ & $-3.69 \pm 0.42^{a b}$ & $-3.13 \pm 0.79^{a}$ \\
\hline$b^{*}$ & $17.45 \pm 0.25^{\mathrm{a}}$ & $15.92 \pm 0.14^{b}$ & $15.90 \pm 0.10^{c}$ & $12.57 \pm 0.88^{d}$ & $11.43 \pm 0.63^{d}$ & $9.39 \pm 0.72^{\mathrm{e}}$ \\
\hline
\end{tabular}

a-e Values with different letters in same row showed statistically significant differences at a $5 \%$ level, according to Duncun's multiple range test.

2013 who have studied the effect of drying temperatures on the nutritional and antioxidant qualities of cumari peppers (capsicum Chinese). Blanched dried samples also showed significantly $(p \leq 0.05)$ lower ash content compared to un-blanched dried samples, such an effect might be due to transfer of minerals from samples to boiling water (Nnamani et al. 2009). Similar results were reported by Gouveia et al. (2014) for common beans (phaseolus valgaris L.) and Tandon, (2006) for dehydrated green pea varieties.

The crude fiber content of dried green beans decreased significantly $(p \leq 0.05)$ with the increase in drying temperature (Table 3). No significant change was found between blanched and un-blanched dried samples. Reis et al. (2013) also showed decrease in crude fibre with increase in drying temperature. Bello et al. (2008) reported that crude fiber consists of cellulose, hemicellulose and lignin components whose compositions are affected during hydration of food and hemicellulose, pectin and hydrocolloids are easily solubilized by high heat and this may be the reason for above reduction in crude fibre content (Udousoro and Etuk., 2012).

Carbohydrate content of all dried green beans presented in Table 3 was found in the range 46.38 - $46.86 \%$ after drying. Blanched dried samples showed significantly $(p \leq 0.05)$ more carbohydrate content than un-blanched dried samples which might be attributed to the breakdown of ketogenic amino acids to glucose during blanching thereby increasing the carbohydrate content of dried green bean samples (Fadupin et al. 2014). Similar trend was also reported by Traore et al. (2017) in dehydrated amaranth leaves. Also there was a significant $(p \leq 0.05)$ increase in carbohydrate content with increase in drying temperature. Carbohydrate content depends on the other parameters of dried green beans as it is calculated from moisture, ash content, protein content, fat content and crude fiber. Alakali et al. (2015) also reported similar behaviour in dehydrated moringa oleifera leaves.
Rehydration Ratio (RR)

Rehydration is one of the important properties used to measure the quality of dried food materials (Lewicki, 1998). It can also be considered as a measure of the injury caused by drying or treatment preceding drying. A high value of rehydration ratio means the dried product has good quality because the pores allow water to re-enter the cells (Noomhorm, 2007). The rehydrated samples of un-blanched and blanched dried green bean samples are shown in Figure 4 and 5 respectively. The rehydration ratio of dried green bean samples increased significantly $(P \leq 0.05)$ from 3.26 to 3.95 (un-blanched dried) and 4.41 to 5.14 (blanched dried) as the drying temperature was increased from 50 to $70^{\circ} \mathrm{C}$ respectively. This increase in RR might be due to the fact that the rate of moisture removal at higher temperature was very fast and causes less shrinkage of dried samples and exhibit higher RR in dried green peas (Shete et al., (2015). Blanched samples also showed higher RR than un-blanched samples and this behaviour may be attributed to cellular and structural disruption caused during blanching which might have contributed to the increase the RR of green beans. Similar change in behaviour was also observed by Al-Amin et al. (2015) in dehydrated carrots.

\section{Chlorophyll content}

Chlorophylls are the pigments that confer green color to foods of plant origin. These pigments are particularly unstable under most conditions relevant for food processing and preservation (Belitz et al., 2009; Koca et al., 2006). The loss of green color and the color change to yellow or brown hues is due to chlorophyll degradation (Hortensteiner \& Krautler, 2011). The chlorophyll content of dried green beans dried at different temperatures are presented in Table 3 and was found in the range of $64.29-82.51 \mathrm{mg} / 100 \mathrm{~g}$ (un-blanched dried) and $73.78-88.54 \mathrm{mg} / 100 \mathrm{~g}$ (blanched dried) after 
drying at a temperature range of $50-70^{\circ} \mathrm{C}$ respectively. Blanched dried samples showed significantly $(P \leq 0.05)$ higher chlorophyll content in comparison to un-blanched dried samples. Results found here are in contradiction with Priyanka et al. (2017) in green beans, Pavani and Aduri, (2018) in green leafy vegetables, might be due to the effect of sodium bicarbonate used in blanching solution. Sodium bicarbonate has a positive effect on stability of chlorophyll as it reacts with chlorophyll, displacing the phytyl group forming a bright green chlorophyllide (Srilakshmi, 2003). In addition, sodium bicarbonate increases the medium $\mathrm{pH}$ which, by itself, improves chlorophyll stability as it leads to equilibrium between positive and negative charges, decreases chlorophyll degradation (Von Elbe, 2000). The most important positive impact of blanching with sodium bicarbonate is the removal of phytyl chain, otherwise it would react with singlet oxygen, or hydroxyl and peroxy radicals generated during chlorophyll degradation (Rontani et al., 1995). Singlet oxygen radical attacks the double bonds of the chlorophylls directly, producing hydroperoxides that are further cleaved to produce radicals (Chen and Huang, 1998). Additionally the chlorophyll content decreased with the increase the drying temperature, that might be attributed to the conversion of chlorophylls to pheophytins at higher temperatures (Steel and Tong, 1996; Yin et al., 2007; Koca et al., 2006).

\section{Colorvalues}

Color is a major food quality attribute. Color change is a quality criterion for assessing the quality of dried products. The results of color parameters are presented in Table 3. The $L^{*}$ and $-a^{*}$ value, which show the whiteness and greenness of the product, ranged between $21.02 \& 41.76$ and -3.13 $\&-4.78$ respectively after drying. Blanched dried green beans were found to have lower $L^{*},-a^{*}$ and $b^{*}$ values than un-blanched samples. This means that blanched samples were darker green in color (lower - $a^{*}$ value and lower $b^{*}$ value) than un-blanched samples that were lighter green in color (higher $L^{*}$ values; higher - $a^{*}$ values) after drying as shown in Figure 2 and 3 . Such an effect might be due to destruction of browning enzymes during blanching which would otherwise cause browning. The results are in agreement with findings of Pathare et al., 2013. As the drying temperature was increased the hunter values showed decreasing trend because of Mailard reaction caused by higher temperature. In addition, higher temperature changing color from green or bright

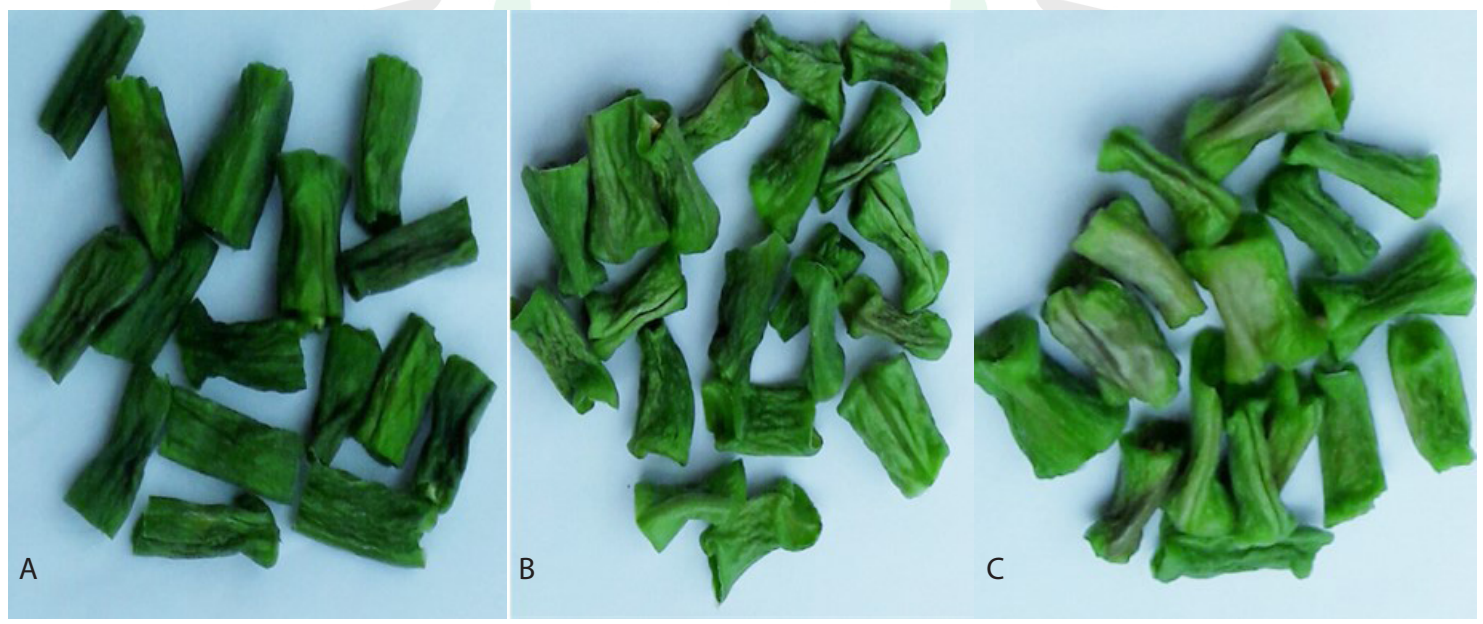

Figure 4: Rehydrated un-blanched sample and dried at (a) 50, (b) 60 and (c) $70^{\circ} \mathrm{C}$

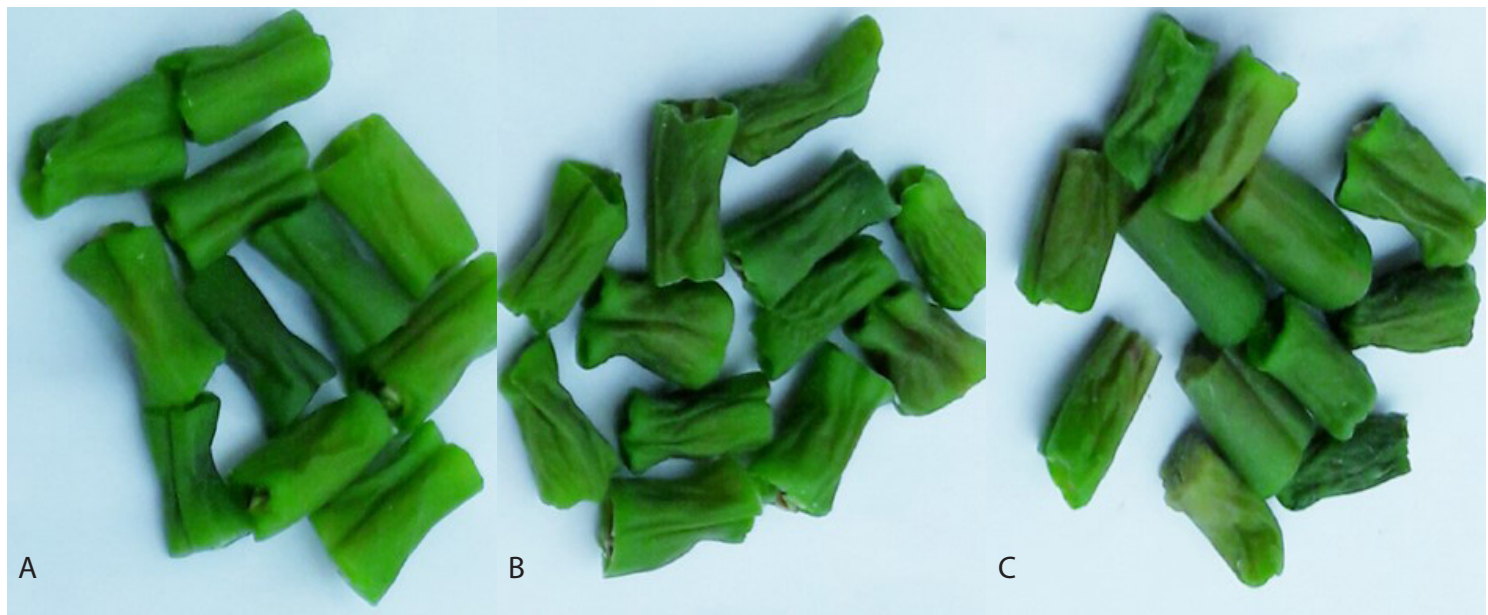

Figure 5: Rehydrated blanched sample and dried at (a) 50, (b) 60 and (c) $70^{\circ} \mathrm{C}$ 
green to olive brown as a consequence of conversion of chlorophyll to pheophytin (Steel and Tong, 1996) and higher accumulation of pheophytins decreasing-a* coordinate (Weemas et al., 1999). Doymaz et al. (2015)a also found same trend while working on characteristics of thin-layer infared drying of green beans.

\section{Storage study of the dried green beans}

\section{Changes in proximate composition during storage}

As the days of storage progressed, the moisture content of all dried green bean samples packed in different packaging materials increased significantly $(p \leq 0.05)$ shown in Table 4. This increase in moisture content might be due to the hygroscopic nature of dried vegetables that absorb the atmospheric moisture during storage. Singh et al. (2003); Kalaskar et al. (2012); Seevaratnam et al. (2012) also reported the similar behavior during storage of green leafy vegetables. With regard to packaging materials, a significant change was found between HDPE and LDPE, the rate of increase in moisture was low in samples packed in HDPE compared to LDPE during storage. This effect might be attributed to less permeability of HDPE film to water vapor compared to LDPE (Singh and Sagar, 2010).

Changes in ash, protein, fat and fiber content during storage are presented in Table 4. With the increase in storage progression, the ash content, protein content, fat content and fiber content of all dried green bean samples showed a nonsignificant change between storage periods and packaging materials. The ash and fiber could not be decreased during storage as it is the inorganic residue remained after the water and organic matter. Singh et al. (2003) also reported nonsignificant change in ash content and protein during storage in dehydrated carrot and leafy vegetables.

Changes in carbohydrate content of dried green beans during storage are shown in Table 4. As the days of storage progressed, the carbohydrate content of all dried green bean samples showed significantly $(p \leq 0.05)$ decreasing trend. Regarding the mode of packaging, samples packed in HDPE and LDPE show a significant change in carbohydrate content during storage. This decrease in carbohydrate content might be due to increase in moisture of dried green beans with storage which resulted in decrease in carbohydrate content as it was calculated from difference method Mills \& Woods1994).

\section{Changes in rehydration ratio during storage}

The changes in rehydration ratio of dried green beans during storage are shown in Table 5 . With regard to storage, the rehydration ratio showed significantly $(p \leq 0.05)$ decreasing trend with increase in storage period. This decreased pattern in rehydration ratio during storage may be attributed to moisture stress, structural and chemical changes during storage, Gupta et al. (2012). Similar trend was also reported by Kalaskar et al. (2012), Singh and Sagar, (2010). HDPE film showed higher values of RR than LDPE which might be due to less absorption of moisture in HDPE during storage. Similar behaviour was reported by Pavani and Aduri, (2018) during the rehydration of dried amaranth.

\section{Changes in chlorophyll content during storage}

Initial chlorophyll content of dried green beans was higher in blanched dried green beans (Table 5). As the days of storage progressed, a significant $(\mathrm{P} \leq 0.05)$ decrease in chlorophyll content of all green bean samples types was observed, the decrease in chlorophyll was witnessed in samples packed wither in LDPE or HDPE. This decrease in chlorophyll content during storage might be due to its oxidation which might have contribution in conversion of chlorophyll to pheophytin (Kalaskar et al., 2012). The similar trend was also reported by Singh and Sagar, (2010); Seevaratnam et al. (2012); Rajeshwari et al. (2013); Pavani and Aduri, (2018). The samples packed in HDPE were found to have significantly $(P \leq 0.05)$ higher chlorophyll content than samples packed in LDPE which might be due to prevention of conversion of chlorophyll to pheophytin due to its less oxidation as HDPE films have good oxygen barrier properties than LDPE films (Singh and Sagar, 2010). Pavani and Aduri, (2018) also observed the similar pattern of behaviour during storage.

\section{Changes in color values $\left(L^{*} a^{*} b^{*}\right)$ during storage}

Effect of storage on $L^{*} a^{*}$ and $b^{*}$ values are shown in Table 5. During the storage the color values $\left(L^{*}, a^{*}\right.$ and $\left.b^{*}\right)$ in un-blanched as well as blanched dried samples showed decreasing with the storage time. This decrease in lightness and greenness $\left(L^{*} a^{*} b^{*}\right)$ could be indicative of pigment oxidation, loss of green color and as a result of browning upon storage. Regarding mode of packaging, HDPE showed high retention of $L^{*} a^{*} b^{*}$ values than LDPE, as HDPE has higher oxygen barrier properties than LDPE which might have contribution in prevention of conversion of chlorophyll to pheophytin due to the pigment oxidation (Singh and Sagar, 2010). These results are also in agreement with findings of Natabirwa et al. (2016) in leafy vegetables.

\section{Conclusion}

Three minutes blanching in boiling water caused complete inactivation of peroxidase in green beans. Blanched samples showed shorter drying time than un-blanched samples due to tissue softening resulting in faster moisture removal by enhancing moisture transfer from inside the samples. Loss of mineral due dissolution of minerals during blanching caused slight loss in mineral content of the blanched dried beans than un-blanched samples. Blanching treatment was found to assist in retaining more chlorophyll pigment thus the color of blanched samples was more appealing. The rehydration ratio of dried green bean samples increased from 3.26 to 3.95 (un-blanched dried) and 4.41 to 5.14 (blanched dried) as the drying temperature was increased from 50 to $70^{\circ} \mathrm{C}$ respectively. During the storage of 60 days no change was observed in ash, protein, fat and fiber content of the dried green beans however slight decrease in carbohydrate and chlorophyll content was witnessed possibly due to biochemical degradation with storage time. Rehydration ratio was found to decrease during storage, however decrease in 
Effect of Blanching and Drying Temperatures on Various Physico-chemical Characteristics of Green Beans

Table 4: Change in proximate composition of dried green beans during storage

\begin{tabular}{|c|c|c|c|c|c|c|c|c|}
\hline \multirow{3}{*}{ Parameters } & \multirow{3}{*}{$\begin{array}{l}\text { Packaging } \\
\text { material }\end{array}$} & \multirow{3}{*}{$\begin{array}{l}\text { Storage } \\
\text { days }\end{array}$} & \multicolumn{6}{|c|}{ Drying temperatures } \\
\hline & & & \multicolumn{3}{|c|}{ Un-blanched dried } & \multicolumn{3}{|l|}{ Blanched dried } \\
\hline & & & $50^{\circ} \mathrm{C}$ & $60^{\circ} \mathrm{C}$ & $70^{\circ} \mathrm{C}$ & $50^{\circ} \mathrm{C}$ & $60^{\circ} \mathrm{C}$ & $70^{\circ} \mathrm{C}$ \\
\hline \multicolumn{9}{|l|}{ Moisture \% } \\
\hline & HDPE & 0 & $14.09 \pm 0.00^{\mathrm{e}}$ & $14.00 \pm 0.11^{\mathrm{e}}$ & $13.90 \pm 0.15^{\mathrm{e}}$ & $14.00 \pm 0.11^{\mathrm{e}}$ & $13.96 \pm 0.08^{\mathrm{e}}$ & $13.88 \pm 0.05^{\mathrm{e}}$ \\
\hline & & 30 & $14.55 \pm 0.09^{d}$ & $14.40 \pm 0.09^{d}$ & $14.23 \pm 0.05^{d}$ & $14.24 \pm 0.04^{d}$ & $14.23 \pm 0.05^{d}$ & $14.16 \pm 0.08^{d}$ \\
\hline & & 60 & $14.85 \pm 0.05^{b}$ & $14.74 \pm 0.10^{\mathrm{b}}$ & $14.60 \pm 0.10^{b}$ & $14.60 \pm 0.05^{\mathrm{b}}$ & $14.60 \pm 0.10^{b}$ & $14.47 \pm 0.13^{b}$ \\
\hline & LDPE & 0 & $14.09 \pm 0.00^{e}$ & $14.00 \pm 0.11^{\mathrm{e}}$ & $13.90 \pm 0.15^{\mathrm{e}}$ & $14.00 \pm 0.11^{\mathrm{e}}$ & $13.96 \pm 0.08^{\mathrm{e}}$ & $13.88 \pm 0.05^{\mathrm{e}}$ \\
\hline & & 30 & $14.67 \pm 0.06^{c}$ & $14.60 \pm 0.08^{c}$ & $14.40 \pm 0.05^{c}$ & $14.30 \pm 0.05^{c}$ & $14.29 \pm 0.00^{c}$ & $14.29 \pm 0.11^{c}$ \\
\hline & & 60 & $14.92 \pm 0.06^{\mathrm{a}}$ & $14.87 \pm 0.06^{\mathrm{a}}$ & $14.70 \pm 0.05^{\mathrm{a}}$ & $14.84 \pm 0.10^{\mathrm{a}}$ & $14.71 \pm 0.05^{\mathrm{a}}$ & $14.68 \pm 0.10^{a}$ \\
\hline \multicolumn{9}{|l|}{ Ash \% } \\
\hline & HDPE & 0 & $4.87 \pm 0.13^{\mathrm{a}}$ & $4.58 \pm 0.11^{\mathrm{a}}$ & $4.33 \pm 0.06^{\mathrm{a}}$ & $4.41 \pm 0.02^{\mathrm{a}}$ & $4.13 \pm 0.04^{\mathrm{a}}$ & $3.96 \pm 0.16^{\mathrm{a}}$ \\
\hline & & 30 & $4.84 \pm 0.12^{\mathrm{a}}$ & $4.55 \pm 0.10^{\mathrm{a}}$ & $4.28 \pm 0.06^{\mathrm{a}}$ & $4.38 \pm 0.04^{\mathrm{a}}$ & $4.10 \pm 0.05^{\mathrm{a}}$ & $3.93 \pm 0.07^{\mathrm{a}}$ \\
\hline & & 60 & $4.82 \pm 0.11^{\mathrm{a}}$ & $4.53 \pm 0.11^{\mathrm{a}}$ & $4.25 \pm 0.07^{a}$ & $4.34 \pm 0.04^{\mathrm{a}}$ & $4.07 \pm 0.04^{\mathrm{a}}$ & $3.90 \pm 0.08^{\mathrm{a}}$ \\
\hline & LDPE & 0 & $4.87 \pm 0.13^{\mathrm{a}}$ & $4.58 \pm 0.11^{\mathrm{a}}$ & $4.33 \pm 0.06^{\mathrm{a}}$ & $4.41 \pm 0.02^{\mathrm{a}}$ & $4.13 \pm 0.04^{\mathrm{a}}$ & $3.96 \pm 0.16^{\mathrm{a}}$ \\
\hline & & 30 & $4.83 \pm 0.11^{\mathrm{a}}$ & $4.54 \pm 0.13^{\mathrm{a}}$ & $4.27 \pm 0.09^{a}$ & $4.36 \pm 0.05^{\mathrm{a}}$ & $4.07 \pm 0.05^{\mathrm{a}}$ & $3.92 \pm 0.08^{\mathrm{a}}$ \\
\hline & & 60 & $4.79 \pm 0.10^{\mathrm{a}}$ & $4.51 \pm 0.10^{\mathrm{a}}$ & $4.23 \pm 0.11^{\mathrm{a}}$ & $4.34 \pm 0.04^{\mathrm{a}}$ & $4.05 \pm 0.05^{\mathrm{a}}$ & $3.88 \pm 0.10^{\mathrm{a}}$ \\
\hline \multicolumn{9}{|l|}{ Protein \% } \\
\hline & HDPE & 0 & $18.29 \pm 0.20^{\mathrm{a}}$ & $18.25 \pm 0.16^{a}$ & $18.23 \pm 0.10^{\mathrm{a}}$ & $18.18 \pm 0.11^{\mathrm{a}}$ & $18.15 \pm 0.11^{\mathrm{a}}$ & $18.12 \pm 0.11^{a}$ \\
\hline & & 30 & $18.19 \pm 0.26^{a}$ & $18.13 \pm 0.24^{\mathrm{a}}$ & $18.16 \pm 0.23^{a}$ & $18.11 \pm 0.15^{a}$ & $18.05 \pm 0.26^{a}$ & $18.09 \pm 0.22^{a}$ \\
\hline & & 60 & $18.09 \pm 0.25^{\mathrm{a}}$ & $18.04 \pm 0.22^{a}$ & $18.08 \pm 0.25^{a}$ & $18.03 \pm 0.13^{a}$ & $18.05 \pm 0.13^{\mathrm{a}}$ & $18.03 \pm 0.24^{a}$ \\
\hline & LDPE & 0 & $18.29 \pm 0.20^{a}$ & $18.25 \pm 0.16^{\mathrm{a}}$ & $18.23 \pm 0.10^{a}$ & $18.18 \pm 0.11^{\mathrm{a}}$ & $18.15 \pm 0.11^{\mathrm{a}}$ & $18.12 \pm 0.11^{a}$ \\
\hline & & 30 & $18.11 \pm 0.24^{\mathrm{a}}$ & $18.06 \pm 0.21^{\mathrm{a}}$ & $18.11 \pm 0.22^{\mathrm{a}}$ & $18.01 \pm 0.23^{a}$ & $18.00 \pm 0.24^{\mathrm{a}}$ & $18.00 \pm 0.25^{\mathrm{a}}$ \\
\hline & & 60 & $18.05 \pm 0.27^{\mathrm{a}}$ & $18.00 \pm 0.25^{\mathrm{a}}$ & $18.06 \pm 0.20^{\mathrm{a}}$ & $18.00 \pm 0.24^{\mathrm{a}}$ & $17.98 \pm 0.23^{\mathrm{a}}$ & $17.97 \pm 0.22^{\mathrm{a}}$ \\
\hline \multicolumn{9}{|l|}{ Fat $\%$} \\
\hline & HDPE & 0 & $2.07 \pm 0.06^{a}$ & $2.01 \pm 0.05^{\mathrm{a}}$ & $1.99 \pm 0.02^{\mathrm{a}}$ & $2.06 \pm 0.06^{\mathrm{a}}$ & $1.98 \pm 0.03^{\mathrm{a}}$ & $1.98 \pm 0.03^{\mathrm{a}}$ \\
\hline & & 30 & $2.06 \pm 0.06^{\mathrm{a}}$ & $2.01 \pm 0.05^{\mathrm{a}}$ & $1.96 \pm 0.05^{\mathrm{a}}$ & $2.06 \pm 0.06^{\mathrm{a}}$ & $1.97 \pm 0.04^{\mathrm{a}}$ & $1.96 \pm 0.06^{\mathrm{a}}$ \\
\hline & & 60 & $2.03 \pm 0.05^{a}$ & $2.00 \pm 0.06^{\mathrm{a}}$ & $1.95 \pm 0.04^{\mathrm{a}}$ & $2.03 \pm 0.07^{\mathrm{a}}$ & $1.97 \pm 0.03^{\mathrm{a}}$ & $1.95 \pm 0.05^{\mathrm{a}}$ \\
\hline & LDPE & 0 & $2.07 \pm 0.06^{\mathrm{a}}$ & $2.01 \pm 0.05^{\mathrm{a}}$ & $1.99 \pm 0.02^{\mathrm{a}}$ & $2.06 \pm 0.06^{\mathrm{a}}$ & $1.98 \pm 0.03^{\mathrm{a}}$ & $1.98 \pm 0.03^{\mathrm{a}}$ \\
\hline & & 30 & $2.03 \pm 0.05^{a}$ & $1.99 \pm 0.05^{\mathrm{a}}$ & $1.95 \pm 0.05^{\mathrm{a}}$ & $2.01 \pm 0.09^{a}$ & $1.96 \pm 0.06^{\mathrm{a}}$ & $1.95 \pm 0.04^{\mathrm{a}}$ \\
\hline & & 60 & $2.02 \pm 0.06^{\mathrm{a}}$ & $1.97 \pm 0.04^{\mathrm{a}}$ & $1.94 \pm 0.04^{\mathrm{a}}$ & $2.00 \pm 0.04^{\mathrm{a}}$ & $1.96 \pm 0.03^{\mathrm{a}}$ & $1.94 \pm 0.04^{a}$ \\
\hline \multicolumn{9}{|l|}{ Fibre \% } \\
\hline & HDPE & 0 & $15.06 \pm 0.11^{\mathrm{a}}$ & $14.90 \pm 0.08^{\mathrm{a}}$ & $14.69 \pm 0.09^{a}$ & $14.97 \pm 0.10^{\mathrm{a}}$ & $14.77 \pm 0.11^{\mathrm{a}}$ & $14.59 \pm 0.11^{a}$ \\
\hline & & 30 & $15.00 \pm 0.17^{a}$ & $14.82 \pm 0.15^{\mathrm{a}}$ & $14.65 \pm 0.16^{a}$ & $14.90 \pm 0.17^{a}$ & $14.70 \pm 0.17^{a}$ & $14.52 \pm 0.17^{a}$ \\
\hline & & 60 & $14.96 \pm 0.11^{\mathrm{a}}$ & $14.77 \pm 0.10^{a}$ & $14.60 \pm 0.09^{a}$ & $14.87 \pm 0.10^{a}$ & $14.64 \pm 0.13^{a}$ & $14.46 \pm 0.12^{a}$ \\
\hline & LDPE & 0 & $15.06 \pm 0.11^{\mathrm{a}}$ & $14.90 \pm 0.08^{a}$ & $14.69 \pm 0.09^{a}$ & $14.97 \pm 0.10^{a}$ & $14.77 \pm 0.11^{\mathrm{a}}$ & $14.59 \pm 0.11^{\mathrm{a}}$ \\
\hline & & 30 & $14.98 \pm 0.10^{\mathrm{a}}$ & $14.80 \pm 0.17^{a}$ & $14.59 \pm 0.18^{a}$ & $14.87 \pm 0.19^{a}$ & $14.68 \pm 0.18^{a}$ & $14.47 \pm 0.19^{a}$ \\
\hline & & 60 & $14.95 \pm 0.11^{\mathrm{a}}$ & $14.75 \pm 0.12^{\mathrm{a}}$ & $14.53 \pm 0.15^{\mathrm{a}}$ & $14.95 \pm 0.13^{a}$ & $14.62 \pm 0.15^{\mathrm{a}}$ & $14.42 \pm 0.15^{\mathrm{a}}$ \\
\hline \multicolumn{9}{|c|}{ Carbohydrate \% } \\
\hline & HDPE & 0 & $45.62 \pm 0.10^{\mathrm{a}}$ & $46.26 \pm 0.15^{a}$ & $46.86 \pm 0.11^{a}$ & $46.38 \pm 0.10^{\mathrm{ab}}$ & $47.01 \pm 0.12^{\mathrm{a}}$ & $47.47 \pm 0.12^{a}$ \\
\hline & & 30 & $45.36 \pm 0.17^{b}$ & $46.09 \pm 0.04^{b}$ & $46.77 \pm 0.05^{b}$ & $46.31 \pm 0.12^{b}$ & $46.95 \pm 0.19^{b}$ & $47.44 \pm 0.10^{a}$ \\
\hline & & 60 & $45.25 \pm 0.11^{c}$ & $45.92 \pm 0.09^{c}$ & $46.50 \pm 0.07^{d}$ & $46.12 \pm 0.09^{c}$ & $46.79 \pm 0.13^{c}$ & $47.31 \pm 0.12^{b}$ \\
\hline & LDPE & 0 & $45.62 \pm 0.10^{\mathrm{a}}$ & $46.26 \pm 0.10^{a}$ & $46.86 \pm 0.11^{\mathrm{a}}$ & $46.38 \pm 0.10^{\mathrm{ab}}$ & $47.01 \pm 0.12^{\mathrm{a}}$ & $47.47 \pm 0.12^{\mathrm{a}}$ \\
\hline & & 30 & $45.38 \pm 0.17^{b}$ & $45.97 \pm 0.18^{c}$ & $46.68 \pm 0.07^{c}$ & $46.45 \pm 0.12^{\mathrm{a}}$ & $47.00 \pm 0.12^{\mathrm{a}}$ & $47.39 \pm 0.15^{b}$ \\
\hline & & 60 & $45.27 \pm 0.14^{c}$ & $45.87 \pm 0.06^{d}$ & $46.59 \pm 0.18^{d}$ & $45.97 \pm 0.13^{d}$ & $46.77 \pm 0.07^{c}$ & $47.17 \pm 0.07^{c}$ \\
\hline
\end{tabular}

\footnotetext{
${ }^{\mathrm{a}-\mathrm{e}}$ Values with different letters in columns showed statistically significant differences at a $5 \%$ level, according to Duncun's multiple range test.

RR was higher in samples stored LDPE than HDPE, and the differences might be due to difference in moisture barrier properties of the packaging material. The color parameters showed decrease with storage time and no difference in

decrease in color parameters was observed in between the two packaging materials. Therefore, it was concluded that blanching of green beans not only affects the color of the green beans but the drying behaviour as well, additionally
} 
Table 5: Change in rehydration ratio, chlorophyll content and color parameters of dried green beans during storage

\begin{tabular}{|c|c|c|c|c|c|c|c|c|}
\hline \multirow{3}{*}{ Parameters } & \multirow{3}{*}{$\begin{array}{l}\text { Packaging } \\
\text { materials }\end{array}$} & \multirow{3}{*}{$\begin{array}{l}\text { Storage } \\
\text { days }\end{array}$} & \multicolumn{6}{|c|}{ Drying temperatures } \\
\hline & & & \multicolumn{3}{|c|}{ Un-blanched dried } & \multicolumn{3}{|c|}{ Blanched dried } \\
\hline & & & $50^{\circ} \mathrm{C}$ & $60^{\circ} \mathrm{C}$ & $70^{\circ} \mathrm{C}$ & $50^{\circ} \mathrm{C}$ & $60^{\circ} \mathrm{C}$ & $70^{\circ} \mathrm{C}$ \\
\hline \multicolumn{9}{|c|}{ Rehydration ratio (g water/g dry matter) } \\
\hline & HDPE & 0 & $2.26 \pm 0.10^{\mathrm{a}}$ & $2.73 \pm 0.05^{\mathrm{a}}$ & $2.93 \pm 0.04^{\mathrm{a}}$ & $3.41 \pm 0.10^{\mathrm{a}}$ & $3.75 \pm 0.08^{\mathrm{a}}$ & $4.14 \pm 0.09^{a}$ \\
\hline & & 30 & $2.14 \pm 0.05^{\mathrm{b}}$ & $2.65 \pm 0.04^{b}$ & $2.86 \pm 0.05^{\mathrm{b}}$ & $3.24 \pm 0.06^{\mathrm{b}}$ & $3.63 \pm 0.06^{\mathrm{b}}$ & $4.05 \pm 0.05^{b}$ \\
\hline & & 60 & $2.04 \pm 0.03^{c}$ & $2.54 \pm 0.06^{c}$ & $2.76 \pm 0.08^{c}$ & $3.15 \pm 0.06^{c}$ & $3.54 \pm 0.05^{c}$ & $3.96 \pm 0.06^{c}$ \\
\hline & LDPE & 0 & $2.26 \pm 0.10^{\mathrm{a}}$ & $2.73 \pm 0.05^{\mathrm{a}}$ & $2.93 \pm 0.04^{\mathrm{a}}$ & $3.41 \pm 0.10^{\mathrm{a}}$ & $3.75 \pm 0.08^{\mathrm{a}}$ & $4.14 \pm 0.09^{a}$ \\
\hline & & 30 & $2.05 \pm 0.07^{c}$ & $2.56 \pm 0.08^{c}$ & $2.76 \pm 0.08^{c}$ & $3.10 \pm 0.08^{c}$ & $3.53 \pm 0.08^{c}$ & $3.97 \pm 0.06^{c}$ \\
\hline & & 60 & $1.96 \pm 0.05^{d}$ & $2.46 \pm 0.07^{d}$ & $2.68 \pm 0.07^{d}$ & $3.00 \pm 0.08^{d}$ & $3.45 \pm 0.09^{d}$ & $3.90 \pm 0.05^{d}$ \\
\hline \multicolumn{9}{|c|}{ Total chlorophyll (mg/100g) } \\
\hline & HDPE & 0 & $82.51 \pm 0.09^{a}$ & $73.22 \pm 0.14^{\mathrm{a}}$ & $64.29 \pm 0.17^{a}$ & $88.54 \pm 0.19^{a}$ & $79.93 \pm 0.17^{a}$ & $73.78 \pm 0.15^{\mathrm{a}}$ \\
\hline & & 30 & $80.28 \pm 0.16^{\mathrm{b}}$ & $69.58 \pm 0.15^{\mathrm{b}}$ & $62.54 \pm 0.16^{\mathrm{b}}$ & $86.97 \pm 0.16^{\mathrm{b}}$ & $78.57 \pm 0.16^{b}$ & $71.64 \pm 0.16^{b}$ \\
\hline & & 60 & $78.79 \pm 0.15^{c}$ & $67.93 \pm 0.17^{d}$ & $61.49 \pm 0.14^{c}$ & $84.67 \pm 0.18^{d}$ & $76.02 \pm 0.14^{d}$ & $70.33 \pm 0.18^{c}$ \\
\hline & LDPE & 0 & $82.51 \pm 0.09^{a}$ & $73.22 \pm 0.14^{\mathrm{a}}$ & $64.29 \pm 0.17^{a}$ & $88.54 \pm 0.19^{a}$ & $79.93 \pm 0.17^{a}$ & $73.78 \pm 0.15^{a}$ \\
\hline & & 30 & $76.94 \pm 0.14^{d}$ & $68.17 \pm 0.16^{c}$ & $61.33 \pm 0.19^{\mathrm{cd}}$ & $85.30 \pm 0.13^{c}$ & $76.37 \pm 0.19^{c}$ & $69.45 \pm 0.17^{d}$ \\
\hline & & 60 & $76.44 \pm 0.16^{\mathrm{e}}$ & $65.04 \pm 0.14^{\mathrm{e}}$ & $59.17 \pm 0.18^{\mathrm{e}}$ & $83.17 \pm 0.18^{\mathrm{e}}$ & $73.80 \pm 0.15^{\mathrm{e}}$ & $68.60 \pm 0.15^{\mathrm{e}}$ \\
\hline \multicolumn{9}{|c|}{ Colour values } \\
\hline \multirow{6}{*}{$L^{*}$ value } & HDPE & 0 & $41.76 \pm 0.98^{a}$ & $40.08 \pm 0.22^{a}$ & $36.66 \pm 0.57^{a}$ & $24.90 \pm 0.26^{\mathrm{a}}$ & $21.94 \pm 0.52^{\mathrm{a}}$ & $21.02 \pm 0.18^{a}$ \\
\hline & & 30 & $36.78 \pm 0.39^{b}$ & $36.01 \pm 0.28^{b}$ & $35.33 \pm 0.38^{\mathrm{b}}$ & $23.71 \pm 0.47^{b}$ & $20.99 \pm 0.39^{b}$ & $20.37 \pm 0.18^{b}$ \\
\hline & & 60 & $35.81 \pm 0.70^{c}$ & $35.57 \pm 0.11^{c}$ & $33.55 \pm 0.62^{d}$ & $21.76 \pm 0.18^{c}$ & $20.17 \pm 0.09^{d}$ & $20.04 \pm 0.05^{c}$ \\
\hline & LDPE & 0 & $41.76 \pm 0.98^{a}$ & $40.08 \pm 0.22^{a}$ & $36.66 \pm 0.57^{a}$ & $24.90 \pm 0.96^{\mathrm{a}}$ & $21.94 \pm 0.52^{a}$ & $21.02 \pm 0.18^{a}$ \\
\hline & & 30 & $35.54 \pm 0.31^{c}$ & $33.90 \pm 0.29^{d}$ & $32.76 \pm 0.38^{c}$ & $21.93 \pm 0.11^{c}$ & $20.63 \pm 0.21^{c}$ & $20.03 \pm 0.05^{c}$ \\
\hline & & 60 & $33.07 \pm 0.58^{d}$ & $32.99 \pm 0.18^{e}$ & $30.14 \pm 0.06^{\mathrm{e}}$ & $20.22 \pm 0.39^{d}$ & $20.00 \pm 0.02^{\mathrm{e}}$ & $19.94 \pm 0.05^{d}$ \\
\hline \multirow{6}{*}{$a^{*}$ value } & HDPE & 0 & $-4.78 \pm 0.43^{e}$ & $-4.10 \pm 0.13^{e}$ & $-3.98 \pm 0.16^{d}$ & $-4.57 \pm 0.96^{\mathrm{e}}$ & $-3.69 \pm 0.42^{d}$ & $-3.13 \pm 0.79^{e}$ \\
\hline & & 30 & $-4.20 \pm 0.34^{d}$ & $-3.83 \pm 0.12^{d}$ & $-2.63 \pm 0.35^{c}$ & $-3.48 \pm 0.16^{d}$ & $-2.22 \pm 0.16^{c}$ & $-1.66 \pm 0.15^{d}$ \\
\hline & & 60 & $-3.51 \pm 0.15^{b}$ & $-2.44 \pm 0.12^{b}$ & $-2.25 \pm 0.12^{b}$ & $-2.99 \pm 0.11^{b}$ & $-1.90 \pm 0.26^{b}$ & $-1.38 \pm 0.19^{c}$ \\
\hline & LDPE & 0 & $-4.78 \pm 0.43^{e}$ & $-4.10 \pm 0.13^{e}$ & $-3.98 \pm 0.16^{d}$ & $-4.57 \pm 0.96^{\mathrm{e}}$ & $-3.69 \pm 0.42^{d}$ & $-3.13 \pm 0.79^{e}$ \\
\hline & & 30 & $-3.79 \pm 0.13^{c}$ & $-3.17 \pm 0.22^{c}$ & $-2.45 \pm 0.14^{c}$ & $-3.15 \pm 0.09^{c}$ & $-2.02 \pm 0.21^{b}$ & $-1.17 \pm 0.14^{b}$ \\
\hline & & 60 & $-3.17 \pm 0.17^{a}$ & $-2.30 \pm 0.06^{a}$ & $-2.09 \pm 0.11^{a}$ & $-2.84 \pm 0.09^{a}$ & $-1.74 \pm 0.09^{a}$ & $-1.03 \pm 0.15^{a}$ \\
\hline \multirow{6}{*}{$\mathrm{b}^{*}$ value } & HDPE & 0 & $17.45 \pm 0.25^{\mathrm{a}}$ & $15.92 \pm 0.14^{a}$ & $13.90 \pm 0.10^{a}$ & $12.57 \pm 0.88^{\mathrm{a}}$ & $11.43 \pm 0.63^{a}$ & $9.39 \pm 0.72^{\mathrm{a}}$ \\
\hline & & 30 & $17.14 \pm 0.36^{\mathrm{ab}}$ & $15.68 \pm 0.10^{b}$ & $13.46 \pm 0.16^{b}$ & $10.56 \pm 0.16^{\mathrm{b}}$ & $8.16 \pm 0.03^{b}$ & $7.50 \pm 0.18^{b}$ \\
\hline & & 60 & $16.46 \pm 0.12^{d}$ & $14.83 \pm 0.29^{d}$ & $13.03 \pm 0.18^{d}$ & $9.77 \pm 0.10^{d}$ & $8.11 \pm 0.08^{b c}$ & $7.18 \pm 0.08^{c}$ \\
\hline & LDPE & 0 & $17.45 \pm 0.25^{\mathrm{a}}$ & $15.92 \pm 0.14^{\mathrm{a}}$ & $13.90 \pm 0.10^{\mathrm{a}}$ & $12.57 \pm 0.88^{\mathrm{a}}$ & $11.43 \pm 0.63^{a}$ & $9.39 \pm 0.72^{\mathrm{a}}$ \\
\hline & & 30 & $16.89 \pm 0.14^{c}$ & $15.56 \pm 0.10^{c}$ & $13.23 \pm 0.08^{c}$ & $10.39 \pm 0.10^{c}$ & $7.93 \pm 0.09^{d}$ & $7.08 \pm 0.08^{d}$ \\
\hline & & 60 & $16.08 \pm 0.34^{\mathrm{e}}$ & $14.80 \pm 0.26^{d}$ & $12.16 \pm 0.05^{\mathrm{e}}$ & $9.53 \pm 0.11^{\mathrm{e}}$ & $7.72 \pm 0.13^{\mathrm{e}}$ & $7.01 \pm 0.01^{\mathrm{e}}$ \\
\hline
\end{tabular}

${ }^{a-e}$ Values with different letters in columns showed statistically significant differences at a $5 \%$ level, according to Duncun's multiple range test.

the drying temperature and blanching treatment strongly determines the quality characteristics of the green beans during storage.

\section{References}

Agarwal, A. K., Mishra, N. K., Sandey, K. K. and Sinha, G. (2015). Solar drying of pea: Comparison of various methods considering its dehydration and rehydration characteristics. International Journal of Research Studies in Biosciences, pp: 83-88.

Alakali, J. S., Kucha, C. T and Rabiu, I. A. (2015). Effect of drying temperature on nutritional quality of Moringa oleifera leaves. African Journal of Food Science, 9(7):395-39.
Al-Amin, M., Hossain, M. S., \& lqbal, A. (2015). Effect of pre-treatments and drying methods on dehydration and rehydration characteristics of carrot. Universal Journal of Food and Nutrition Science, 3(2), 23-28.

AOAC, (1990). Association of Official Analytical Chemists. Official Methods of Analysis, 15 ${ }^{\text {th }}$ Edn. AOAC, Washington, D.C, pp: 556.

Barbosa-Canovas, G. V., \& Vega-Mercado, H. (1996). Other methods of dehydration of foods and packaging aspects (Eds.), Dehydration of foods, New York: chapman \& Hall.

Belitz, H. D., Grosch, W., Schieberle, P. (2009). Food Chemistry, $4^{\text {th }}$ edition. Verlag Berlin Heidelberg; Springer.1070.

Bello, M. O., Falade, O. S., Adewusi, S. R., Olawore, N. O. (2008). Studies on the chemical compositions and antinutrients of 
lesser known Nigerian fruits. African. Journal of Biotechnology, 7: 3972-3979.

Chen, B.H., \& Huang, J.H. (1998). Degradation and isomerization of chlorophyll a and \& carotene as affected by various heating and illumination treatments. Food Chemistry, 62 (3), 299-307.

Doymaz, i. (2005). Drying behaviour of green beans. Journal offood Engineering, 69(2), 161-165.

Doymaz, I. (2011). Drying of green bean and okra under solar energy. Chemical Industry and Chemical Engineering Quarterly/CICEQ, 17(2), 199-205.

Doymaz, I., Kipcak, A. S., \& Piskin, S. (2015a). Characteristics of thinlayer infrared drying of green bean. Czech Journal of Food Sciences, 33(1), 83-90.

Doymaz, I., Kipcak, A. S., Piskin, S. (2015 b). Microwave drying of green bean slices: Drying kinetics and physical quality. Czech Journal of Food Sciences, 33(4): 367-376.

Doymaz, I., Pala, M. (2002). Hot air drying characteristics of red pepper. Journal of Food Engineering, 55: 331-335.

Ertekin, C., \& Yaldız, O. (2010, June). Thin layer drying of sliced squash by forced convection. In 17th World Congress of the International Commission of Agricultural and Biosystems Engineering (CIGR) (pp. 13-17).

Fadupin, G. T., Osuoji, U., \& Ariyo, O. (2014). Effect of Blanching on Nutrient and Anti-nutrient Content of Pumpkin (cucurbita pepo) Leaves. African Journal of food and nutrition, 12(2): 18-24.

FAOSTAT.(2018). - Food and Agriculture Organization of United State. Available in: http://www.fao.org/home/en. Acessed in February 2018.

Gouveia, C.S.S., Freitas, G., De-Brito, J.H., Slaski, J.J. and De-Carvalho, Miguel A.A.Pinheiro. (2014). Nutritional and mineral variability in 52 accessions of common bean varieties (Phaseolus vulgaris L.) from Madeira Island. AgriculturalSciences, 5: 317-329.

Gunes, B., \& Bayindirh, A. (1993). Peroxidase and lipoxygenase inactivation during blanching of green beans, green peas and carrots. Lebensmittel Wissenschaft und Technologie,26: 406-410.

Gupta, M. K., Sehgal, V. K., Singh, A.K. and Singh, R. K. (2012). Effect of process parameters and storage length on quality of dried cauliflower during storage. Indian Journal of Traditional Knowledge,11(1): 177-184.

Hörtensteiner, S., \& Kräutler, B. (2011). Chlorophyll breakdown in higher plants. Biochimica et Biophysica Acta (BBA)Bioenergetics, 1807(8), 977-988.

Kalaskar, A.B., Sonkamble, A.M. and Patil, P.S. (2012). Studies on drying and dehydration of fenugreek leaves. International Journal of Processing \& Post Harvest Technology, 3(1): 15-17.

Koca, N., Karadeniz, F., \& Burdurlu, H.S. (2006). Effect of pH on chlorophyll degradation and colour loss in blanched green peas. Food Chemistry, 100, 609-15.

Kshetrimayum, R., Shukla, R.N., Mishra, A. (2015). Study on drying andquality characteristics of tray and microwave dried guava slices. International Journal of Science, Engineering and Technology,3(4): 2395-4752.

Laparra, J.M., Glahn, R.P., Miller, D.D. (2009). Assessing potential effect of inulin and probiotic bacteria on Fe availability from common beans (Phaseolus vulgaris L.) to caco-2-cells. Journal of Food Science, 74: 40-46.

Lewicki, P. P. (1998). Some remarks on rehydration of dried foods. Journal of Food Engineering, 36(1): 81-87.

Maldonado, S. G., Marín-Jarillo, A., Castellanos, J. Z., De Mejía, E. G., \& Acosta-Gallegosc, J. A. (1996). Relationship between physical and chemical characteristics and susceptibility to Zabrotes subfasciatus (Boh.)(Coleoptera: Bruchidae) and Acanthoscelides obtectus (Say) in common bean (Phaseolus vulgaris L.) varieties. Journal of Stored Products Research, 32(1), 53-58.

Mills, J. T., \& Woods, S. M. (1994). Factors affecting storage life of farm-stored field peas (Pisum sativum L.) and white beans (Phaseolus vulgaris L.). Journal of Stored Products Research, 30(3), 215-226.

Natabirwa, H., Mukiibi1, J., Zziwa, E and Kabirizi, J. (2016). Nutritional and physicochemical properties of stored solar-dried cowpea leafy vegetables. Uganda Journal of Agricultural Sciences, 17(1): $1-10$.

Nleya, K. M., Minnaar, A., Henriette, L de Kock. (2014). Relating physic-chemical properties of frozen green peas (pisum sativum L.) to sensory quality. Journal of Food Agricultural sciences, $94:$ 857-865.

Nnamani, C.V., Oselebe, H.O., and Agbatutu, A. (2009). Assessment of nutritional values of three underutilized indigenous leafy vegetables of Ebonyi State, Nigeria. African Journal of Biotechnology, 8(9): 2321-2324.

Noomhorm .A. (2007). Overview of dehydration method on quality of fruits and vegetables. SWU Sci. J. 23: 9-22.

Pardeshi, I. L., Arora, S., \& Borker, P. A. (2009). Thin-layer drying of green peas and selection of a suitable thin-layer drying model. Drying Technology, 27(2), 288-295.

Pathare, P.B., Umezuruike, L., Opara., and Fahad, Al-Julanda Al-Said. 2013. Colour measurement and analysis in fresh and processed foods: A review. Food Bioprocess Technology, 6: 36-60.

Pavani, K.V, Aduri, P. (2018). Effect of Packaging Materials on Retention of Quality Characteristics of Dehydrated Green Leafy Vegetables during Storage. International Journal of Environment, Agriculture and Biotechnology,3(1).

Priyanka, K., Chandni, R.C., Sankar, A and. Raghu, A.V. (2017). Effect of solar dehydration method on physico-chemical and sensory characteristics of green beans (phaseolus vulgaris). International Journal of Research Granthaalayah,5(4): 39-44.

Rajeswari, R., Pushpa, B., Naik, K. R., \& Shobha, N. (2013). Dehydration of amaranthus leaves and its quality evaluation. Karnataka Journal of Agricultural Sciences, 26(2), 276-280.

Reis, R .C., Castro, V. C., Devilla, I. A. , Oliveira, C. A., Barbosa, L. S. andRodovalho, R. (2013). Effect of drying temperature on the nutritional and antioxidant qualities of Cumari Peppers from Para (Capsicum chinense Jacqui) Brazilian. Journal of Chemical Engineering, 30(2): 337-343.

Rontani, J., Beker, B., \& Raphael, D. (1995). Photodegradation of chlorophyll phytyl chain in dead phytoplanktonic cells. Journal of Photochemistry and Photobiology, 85, 137-142.

Sadasivam, S. and Manickam, A. (1992). In: Biochemical Methods for Agricultural Sciences, Willey Eastern Ltd., New Delhi, pp: 184-185. 
Seevaratnam, V., Banumathi, P., Premalatha, M. R., Sundaram, S.P and Arumugam, T. (2012). Effect of packaging materials on retention of quality characteristics of selected dehydrated green leafy vegetables during storage.World Journal of Dairy \& Food Sciences,7(2): 190- 194.

Senadeera, W., Bhandari, B. R., Young, G., \& Wijesinghe, B. (2003). Influence of shapes of selected vegetable materials on drying kinetics during fluidized bed drying. Journal of Food Engineering, 58(3), 277-283.

Shete, Y. V., More, M. M., Deshmukh, S. S. and Karne, S. C. (2015). Effects of pretreatments and drying temperatures on quality of dried green peas. International Journal of Agricultural Engineering, 8(2): 220-226.

Singh, G., Kawatra, A., Sehgal, S and Pragati. (2003). Effect of storage on nutritional composition of selected dehydrated green leafy vegetable, herb and carrot powders. Plant Foods for Human Nutrition 58: 1-9.

Singh, U. and Sagar, V. R. (2010). Quality characteristics of dehydrated leafy vegetables influenced by packaging materials and storage temperature. Journal of scientific and Industrial Research, 69: 785-789.

Soares, M. A., Quintela, E. D., Mascarin, G. M., \& Arthurs, S. P. (2015). Effect of temperature on the development and feeding behavior of Acanthoscelides obtectus (Chrysomelidae: Bruchinae) on dry bean (Phaseolus vulgaris L.). Journal of Stored Products Research, 61, 90-96.

Sotelo, A., Argote, R. M., Moreno, R. S., Flores, N. I., Diaz, M. (2003). Nutritive evaluation of the seed, germinated, and string bean of Erythrina Americana and the detoxification of the material by the boiling. Journal of Agricultural Food Chemistry, 51(9): 2821-2825.

Srilakshmi, B. (2003). Food Science. 3rd ed. New Delhi: New Age International (P) Ltd., Publishers. 401p.
Steel, J.A., \& Tong, C.H. (1996). Degradation kinetics of green color and chlorophylls in peas by colorimetry and HPLC. Journal of Food Science, 61(5): 924-928.

Tandon, S. (2006). Nutritional evaluation and processin of pea (Pisum sativum var. sativum) varieties. MSc. Thesis, I.C. College of HomeScience, CCS Haryana Agricultural University, India.

Traore, K., Parkouda, C., Savadogo, A. (2017). Effect of processing methods on the nutritional content of three traditional vegetables leaves: Amaranth, black night shade and jute mallow. Food Science and Nutrition, 5(6): 1139-1144.

Tunde-Akintunde, T. Y., Oyelade, O. J., Akintunde, B. O. (2014). Effect of drying temperatures and pre-treatments on drying characteristics, energy consumption, and quality of bell pepper. Agric Eng Int: CIGR Journal, 16(2): 108-118.

Udousoro, I., Etuk, B. (2012). Effects of Heating Temperature and time on the Nutrients and Antinutrients Composition of Telfairia occidentalis (Hook F.) International Journal of Modern Chemistry, 3(1): 14-22.

Von Elbe, J.H. (2000). Colorants. In: Fennena, O.W., Food chemistry. 3rd ed. Marcel Dekker: Wisconsin-Madison. Chapter 10, 659675.

Watada, A. E., \& Morris, L. L. (1967). Growth and respiration patterns of snap bean fruits. Plant physiology,42(6):757-761.

Weemaes, C. A., Ooms, V., Van Loey, A. M., \& Hendrickx, M. E. (1999). Kinetics of chlorophyll degradation and color loss in heated broccoli juice. Journal of Agricultural and Food Chemistry, 47(6), 2404-2409.

WFLO-World Food Logistics Organization Commodity Storage Mannual. Snap beans/Green beans, (2008). Institute of Food and Agricultural Sciences, Unversity of Floroda.

Yin, Y., Han, Y., \& Liu, J. (2007). A novel protecting method for visual green color in spinach puree treated by high intensity pulsed electric fields. Journal of Food Engineering, 79, 1256-1260. 